\title{
THE Obligations ON GOVERNMENT AND SOCIETY IN OUR CONSTITUTIONAL STATE TO RESPECT AND SUPPORT INDEPENDENT CONSTITUTIONAL STRUCTURES
}

\author{
LWH Ackermann
}

SC. Judge of the Constitutional Court.

\section{Introduction}

When there has been a heavy fall of rain on a newly made and newly grassed football field, you do not chase two football teams on to it to play a match.

These homely but profound remarks were addressed to our small delegation during 1994 when we were visiting Hungary to study its recently adopted new Constitution and its young Constitutional Court. The Hungarian Constitution and its Constitutional Court were then but five years old. The remarks were made by the leader of the opposition in the Hungarian national legislature. This wise, seasoned political campaigner had been criticising some of the recent judgments of the Hungarian Constitutional Court and his remarks were intended to impress on us that, whatever his criticisms might be, he had a deep commitment to the new constitutional state and its independent institutions and that the latter should never be harmed for the sake of political or other gain. Our own Constitution, and the constitutional democracy it guarantees, is also a newly planted field, little more than five years old.

In this paper I propose noting first some of the features of modern constitutionalism and the paradoxes to which they give rise. I then discuss the need for independent constitutional institutions, the substantive independence necessary for their proper functioning and areas where they require special support. I conclude with some observations on the paradox of judicial review, appropriate checks and balances on courts exercising judicial review and the vital importance of distinguishing between honest and informed criticism of judgments and judges and the undermining of the judiciary as a constitutional institution. 


\section{$2 \quad$ Constitutionalism}

"Constitutional democracy" connotes a development in the concept of democracy which began towards the end of the eighteenth century but which has gained more universal recognition only in the last 50 years. On the one hand, constitutional democracy recognises the ancient democratic principle that government of a country is based on and legitimated by the will and consent of the governed (or more accurately the will and consent of the majority of the governed), which is determined by regular multi-party elections based on universal adult franchise. On the other hand, constitutional democracy limits this principle by making the democratically elected government and the will of the majority subject to a written constitution and the norms embodied in it, which constitution is enshrined as the supreme law of the country in question. An almost universal feature of modern constitutionalism is a Bill of Rights which forms part of the Constitution and which is designed to protect and enforce individual rights principally, although not exclusively, against the state. The concept of a constitutional democracy, for which the short-hand expression "constitutionalism" is sometimes used, is a radical one, the full implications of which are not always readily appreciated. It transforms the regulation of the state and those living in it from a political exercise which in principle can be, and in practice sometimes is, value free and dictated by the majority, to one which is shaped and ruled, both directly and indirectly, by the Constitution and its underlying norms and values. In a constitutional state, the politics of governance can never again be a merely pragmatic enterprise aimed exclusively at achieving the various goals comprising the government's electoral mandate. Governance is now subject to the Constitution and its values.

Constitutionalism also embodies the principle of the separation of powers but, in consequence of the bitter lessons of constitutional history, has come to accept the vital need to impose checks and balances on the three arms of the state. Modern constitutionalism has moved strongly away from Plato, who saw the fundamental problem of politics in the question: "Who shall rule the state?" Instead it asks the new and different question: "How can we so organise political institutions that bad or 
incompetent rulers can be prevented from doing too much damage." ${ }^{1}$ This is not an expression of cynicism, but of wisdom gained from the painful lessons of human fallibility and particularly from the attendant fact that no-one can be completely trusted with power and its subtle temptations. A competent and independent judiciary, with the power to review all legislative and executive action which is inconsistent with the Constitution, is regarded, almost universally, as the prime and most effective check on the legislative and executive arms of the state. More recently, however, it has come to be realised that for the truly effective and meaningful operation of constitutionalism other independent state institutions are necessary. The collective objective of these institutions is to ensure that the Constitution in fact produces what it proclaims; that constitutionalism becomes a way of life in all institutional structures.

An invariable consequence of constitutionalism is the tension between the will of the majority, and its representatives, on the one hand, and the normative control of the Constitution, exercised through the courts and other institutions, on the other. This tension, one might even call it a paradox, cannot ever be completely or permanently resolved, an inevitability which is, as yet, inadequately appreciated and I will touch on it later in this paper.

\section{The Need for Independent Institutions}

The South African Constitution has clearly designated the judiciary as the prime upholder and enforcer of the Constitution. While prescribing certain constitutional functions for all courts, the Constitution has conferred a special role in this regard on the Constitutional Court. There are particular historical and fundamental jurisprudential reasons for this which fall outside the ambit of this paper. Apart from those matters in respect of which it has exclusive jurisdiction, ${ }^{2}$ the Constitutional Court is the highest court in all constitutional matters, ${ }^{3}$ which includes issues

See Popper Open Society 120-121.

Enumerated in s 167(4).

S 167(3)(a) of the 1996 Constitution ("the Constitution"). 
connected with a decision on a constitutional matter; ${ }^{4}$ decisions on whether a matter is a constitutional matter or whether an issue is connected with a decision on a constitutional matter; ${ }^{5}$ and any issue involving the interpretation, protection or enforcement of the Constitution. ${ }^{6}$ In fact the Constitutional Court's jurisdiction is even more extensive than the above might superficially suggest, because it also includes the final decision whether, in interpreting any legislation and developing the common law or customary law, every court, tribunal or forum has correctly "promote[d] the spirit, purport and objects of the Bill of Rights."7

The Constitution has, however, gone further in its commitment to strengthening and entrenching constitutionalism and, drawing on the often sad experiences of young democracies in the past, wisely makes provision for a variety of independent state institutions whose purpose is to "strengthen constitutional democracy in the Republic". 8 They are the Public Protector; the Human Rights Commission; the Commission for the Promotion and Protection of the Rights of Cultural, Religious and Linguistic Communities; the Gender Commission; the Auditor-General and the Electoral Commission. Apart from these state institutions the Constitution also makes provision for other independent bodies designed to play an important checking and balancing role. So, for example, in relation to local government, it mandates the establishment of an independent authority for the determination of municipal boundaries, ${ }^{9}$ provides for a Financial and Fiscal Commission which is independent, impartial and subject only to the Constitution and the law ${ }^{10}$ and a Reserve Bank which must perform its functions independently and without fear, favour or prejudice. ${ }^{11}$

One may legitimately ask why it is necessary to make provision for these additional independent institutions. The object is clearly stated by the Constitution in relation to the independent state institutions referred to in section 181 and is to be inferred for the others, namely, to strengthen constitutional democracy in the Republic. From a

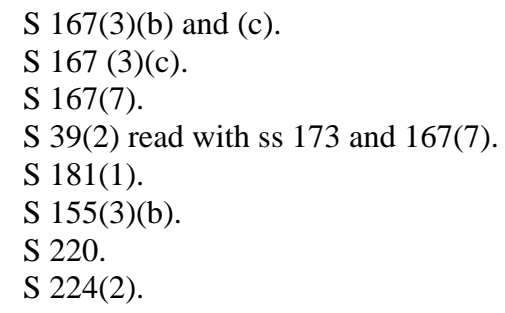


functional point of view this purpose, once stated, strikes one as obvious. Yet it is a truism not always appreciated. The remarkable success of our 1994 and 1999 elections, in the sense that they were substantially free and fair and were accepted as legitimate by the overwhelming majority of the electorate across all political boundaries, can only be ascribed to the competent functioning of the Electoral Commission, whose independence has been guaranteed by both the 1993 and 1996 Constitutions and which was jealously asserted by the Electoral Commission itself. We tend to take this for granted, forgetting in the process how many emerging democracies have stumbled at the hurdle of their first elections, because the results are not accepted as true or legitimate by a suspicious and newly liberated electorate. In my view the significance of these institutions goes even deeper. A homely metaphor has on occasion been used to describe the Constitution as comprising the building blocks for a constitutional democracy, but it warns that they need a pervading human rights ethos to act as the mortar binding these blocks securely together; without such mortar, the structure will remain unstable and liable to topple in severe political storms. The proper functioning of the independent constitutional institutions, including the court system, is vitally important for creating and sustaining such an ethos of constitutionalism amongst the inhabitants of the Republic. The regular effective functioning of these institutions assists in establishing the habits of constitutionalism. It advances constitutionalism from an exercise of the mind to a living practice, even a ritual if you will. Practices and rituals in the life of a nation, as well as in that of an individual, are important. When a nation is seriously shaken by the storms of political life, the demands of the moment can place principle under threat. At such times the ingrained and almost instinctual habits and rituals of constitutionalism may be the last line of defence for the Constitution. The inculcation of these practices and habits are therefore of great importance. It is similarly important to resists all attempts to undermine these institutions and the habits of constitutionalism.

\section{Substantive Independence of these Institutions}

In relation to the judiciary and the other independent state institutions to which reference has been made, the Constitution makes explicit provision for their 
protection and thereby indirectly for the development of these habits of constitutionalism. The independence, dignity, accessibility and effectiveness of the courts are protected both by negative and positive injunctions in the Constitution. ${ }^{12}$ The courts are stated to be independent and subject only to the Constitution and the law; no person or organ of state may interfere with the functioning of the courts; and organs of state, through legislative and other measures, must assist and protect the courts to ensure their independence, impartiality, dignity, accessibility and effectiveness. ${ }^{13}$ Likewise the independent state institutions mentioned are declared by the Constitution to be independent and subject only to the Constitution and the law; other organs of state are obliged by the Constitution, through legislative and other measures, to protect them and to ensure their independence, impartiality, dignity and effectiveness, and no person or organ of state may interfere with the functioning of these institutions. ${ }^{14}$ The protection and support given to these institutions by the Constitution, is very similar to that given to the courts. One important distinction is to be noted. In the case of the courts the Constitution provides that they "are subject only to the Constitution and the law" and no provision is made for them to be accountable to any other organ of state or any other institution or person for that matter. If the term accountability is applicable at all to the courts, about which I have substantial reservations, then courts are "accountable" only to the Constitution and the law, both directly through the Constitution and indirectly through the judicial oath of office. A judge (that is to say a judicial officer on the Constitutional Court, the Supreme Court of Appeal, the High Courts and the courts of a similar status to the High Courts) may only be removed from office if such judge "suffers from an incapacity, is grossly incompetent or is guilty of gross misconduct", has been found as a fact to fall into one or more of those categories by the Judicial Services Commission and a resolution of the National Assembly adopted with a supporting vote of at least two thirds of its members has called for such judge's removal. Provided, therefore, that a judge does not suffer from incapacity, is not grossly incompetent and is not guilty of gross misconduct, she or he is not accountable to any organ of state. By contrast, the independent institutions envisaged in section 181 are expressly made accountable to the National Assembly and are obliged to report on their activities and

12 See s 165(2), (3) and (4).

13 Id. 
the performance of their functions to the Assembly at least once a year. ${ }^{15}$

The independence of state institutions falling outside the legislature and the executive is particularly vulnerable in the area of fiscal and bureaucratic control. While their formal independence may at all times be scrupulously recognised by the legislature and the executive, their substantive independence can easily be undermined by fiscal starvation and their ability to function properly impeded by bureaucratic administrative obstruction or obfuscation or even, quite innocently, by a lack of appreciation of what the Constitution demands from public administration in support of these institutions. If the institutions I am discussing are to function truly independently and to fulfil properly the significant roles assigned to them by the Constitution, safeguards must be devised and implemented in these areas. While certain mechanisms may assist, acceptable independence will only be permanently achieved, I believe, if the right constitutional habits are developed by the organs of state and all citizens come to realise the importance of their own watch-dog functions.

Substantive independence of the courts as required by the Constitution implies much, but chiefly it connotes three things. Firstly, the training and ethical fibre of judges must be such that they can and will be beholden only to the Constitution and its values in performing their judicial duties and not be influenced by other considerations and pressures. Secondly, the judiciary must enjoy reasonable financial security and adequate working conditions in order to attract candidates to judicial office with the requisite training and ethical fibre and also in order to remove the need and temptation, once they are appointed, to look elsewhere in order to maintain an adequate standard of living and in so doing risk sacrificing their independence. Thirdly, their independence must be effectively protected by the Constitution so that no-one, whether within or outside state structures, is able to interfere improperly with the discharge of their duties.

In order for all these aspects of judicial independence to be achieved, the courts require adequate financial and administrative resources. Crucial in this regard is that

14 S 181(2) - (4).

15 S 181(5). 
the process whereby these resources are supplied and controlled should reinforce the independence of the courts and not undermine it. In pursuance of its obligations under section 165(4) of the Constitution, ${ }^{16}$ Parliament has, for example, enacted the Constitutional Court Complementary Act ("the CC Complementary Act"). Apart from other measures designed to assist the Constitutional Court and to strengthen its independence and effectiveness, the CC Complementary Act provides, most commendably, in section 15:

(1) Expenditure in connection with the administration and functioning of the Court shall be defrayed from monies appropriated by Parliament.

(2) Requests for the funds needed for the administration and functioning of the Court, as determined by the President of the Court after consultation with the Minister, shall be addressed to Parliament by the Minister in the manner prescribed for the budgetary processes of departments of state.

Two significant points are to be noted. The first is that the funds needed for the administration and functioning of the Constitutional Court are determined by the President of the Court and by no-one else. While the President of the Court has to consult with the Minister he is not bound by the views expressed by the Minister, nor is he obliged to obtain the approval or consent of the Minister. Secondly the Minister is obliged to address to Parliament a request for such funds as so determined by the President in the above manner. Accordingly, the funding for the administration and functioning of the Constitutional Court is not merely a line item in the budget of the Department of Justice in regard to which the Court might make recommendations only, but would have little control over what is submitted to Parliament. In this way Parliament has gone a long way to securing the independence of the Constitutional Court in regard to its financial needs. The question which arises is whether similar provision ought not to be made in regard to the rest of the judiciary.

16 Which obliges all organs of state, through legislative and other measures to "assist and protect the courts to ensure the independence, dignity, accessibility and effectiveness of the courts." 
Quite clearly Parliament must, even in a constitutional state, control the budgetary processes and expenditure of departments of state and also of the judicial arm of the state. As far as the latter is concerned, this is a sensitive area in the terrain of the separation of powers between the legislature and the judiciary which requires the greatest circumspection and regard for comity between them. The Constitutional Court must not intrude, or be seen to intrude on the fiscal and financial powers of Parliament. ${ }^{17}$ At the same time Parliament must execute these powers in conformity with all its obligations under the Constitution and not in a way which will harm the independence of the judiciary. The same is true of the relationship between the judiciary and the executive in regard to the administration and functioning of the courts. In areas where the contours of these relationships are not spelt out in legislation, and perhaps cannot easily be spelt out, there is need for sound habits and practices of constitutionalism to develop as soon as possible.

\section{Where These Institutions Need Particular Support}

For a number of reasons it has been difficult for these habits and practices to develop. With the benefit of hindsight it is clear that the transition to a constitutional democracy is proving to be slower, more complex and more difficult than initially contemplated and that the coming into operation of the 1996 Constitution did not complete this final stage, it merely introduced it. While this may be a sobering thought, it also reminds us of how thankful we ought to be for the great deal which has already been achieved with relatively little bloodshed and it focuses our attention on the importance of what still has to be done. The process of changing from a racist oligarchy to a constitutional democracy has presented legal, technical, logistic and resource problems which would have been daunting for a country with financial and other resources many times greater than South Africa's. The extent to which and the complexity with which institutionalised apartheid had invaded the legal fabric of society has been underestimated. When the interim Constitution, as it was obliged to do, at one and the same time imploded the existing provincial and local government structures and replaced them with structures which could only take effect

17 For example under chapter 13 of the Constitution. 
incrementally, it made technical legal demands on the legislatures and their technical draftspersons which bordered on the impossible. Provincial governments, which have instruments on their statute books which are clearly inconsistent with the Constitution or are obliged to administer such instruments, have to tread extremely warily before discarding such instruments and must make certain that it is within their legislative competence to do so. Under the Bill of Rights, for example, everyone has the right to equal protection and benefit of the law ${ }^{18}$ under circumstances where equality "includes the full and equal enjoyment of all rights and freedoms"19 and there is an obligation on the government to promote the achievement of equality, ${ }^{20}$ which obligation the government is constitutionally mandated to discharge diligently and without delay. ${ }^{21}$ Any law which is inconsistent with the Constitution became invalid, at the latest, when the 1996 Constitution came into effect. ${ }^{22}$ There is an obligation on government to ensure that such invalidity does not leave a lacuna in the law, which in turn commits government to a massive remedial legislative programme. For the first time in the history of this country the legislatures and executives at all levels of government, represent all the people democratically and are constitutionally equally committed to all the people. The pressures on them, particularly in the national sphere, are enormous. Nevertheless, all South Africans must still be vigilant to ensure, from the outset, that all state organs develop these habits and practices of constitutionalism and that they do not, whether by omission, error or otherwise endanger the independence of our independent state institutions by neglecting their constitutional obligations under section 181(3) "through legislative and other measures [to] assist and protect these institutions to ensure [their] independence, impartiality, dignity and effectiveness."

How easily these obligations can come to be neglected is illustrated by the Constitutional Court's judgment in the New National Party Bar Code case $^{23}$ which dealt amongst other things with the independence of the Electoral Commission ("the Commission"). The Court's judgment points out that, where necessary,

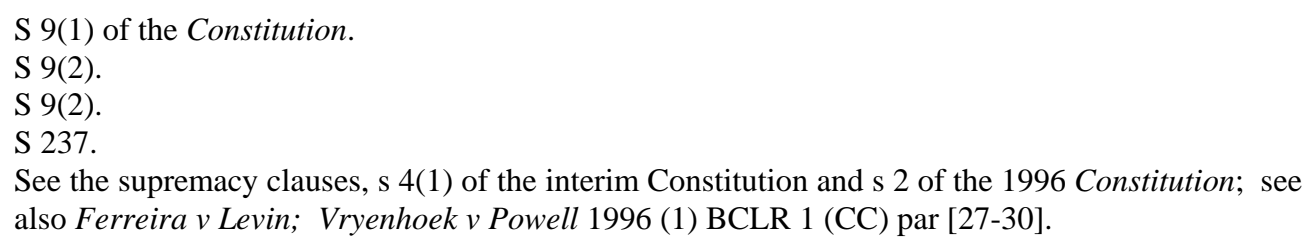


... old legislative and policy arrangements, public administration practices and budgetary conventions must be adjusted to be brought in line with the new constitutional prescripts. ${ }^{24}$

The Departments of Home Affairs and State Expenditure were found to have acted in a way which constituted a serious slight to the dignity and integrity of the Commission $^{25}$ and that the Department of State Expenditure and the Minister of Finance had failed to appreciate the true import of the requirements of the Constitution and the Electoral Commission Act regarding the independence of the Commission and that the Commission was accountable to the National Assembly and not the executive. ${ }^{26}$ The Court emphasised the importance of both financial and administrative independence:

[I]t is necessary to make a distinction between two factors, both of which ... are relevant to "independence". The first is "financial independence". This implies the ability to have access to funds reasonably required to enable the Commission to discharge the functions it is obliged to perform under the Constitution and the Electoral Commission Act. This does not mean that it can set its own budget. Parliament does that. What it does mean, however, is that Parliament must consider what is reasonably required by the Commission and deal with requests for funding rationally, in the light of other national interests. It is for Parliament, and not the executive arm of government, to provide for funding reasonably sufficient to enable the Commission to carry out its constitutional mandate. The Commission must accordingly be afforded an adequate opportunity to defend its budgetary requirements before Parliament or its relevant committees.

The second factor, "administrative independence", implies that there will

23 New National Party of South Africa v Government of the RSA 1999 (5) BCLR 489 (CC).

24 Id par 78.

25 Id par 85.

26 Id par 100. 
be control [by the Commission] over those matters directly connected with the functions which the Commission has to perform under the Constitution and the Act. ... The department cannot tell the Commission how to conduct the registration, whom to employ, and so on; but if the Commission asks the government for assistance to provide personnel to take part in the registration process, government must provide such assistance if it is able to do so. If not, the Commission must be put in funds to enable it to what is necessary. ${ }^{27}$ (Emphasis supplied)

These are general principles applicable to the independence and function of all independent institutions.

\section{The Paradox of Judicial Review and Appropriate Checks and Balances}

The tension or paradox which constitutionalism creates manifests itself most sharply in the relationship between the Constitutional Court and the other two arms of the state at national level, because it is the Constitutional Court which, in the final instance determines whether the actions of the legislature and the executive are consistent with the Constitution and, if not, invalidates them. For the Constitutional Court, in this context, to fulfil its role as the ultimate guardian of the Constitution it must be independent, not only of these organs of state, but also of the political majority. Its members cannot be elected, because that would imply that the Court owed an allegiance or accountability to the political majority or other elector in question. On the other hand, it is seen as undemocratic for a body which is not elected to be in a position to overrule the expressed will of the political representatives of the majority. This paradox, although particularly striking in the case of the Constitutional Court, exists in respect of all our courts and makes the method of appointing judicial officers particularly important in order to ensure at the same time, and as far as this is practically possible, both their independence and their legitimacy. This brings me to the point I want to stress particularly. The judiciary is not, and ought not to be seen as, an arm of the state which has been exempted from all

27 Id pars 98-99. 
checks and balances. At the same time it is important, particularly so for the general public, to appreciate that the checks and balances on the judiciary are not the same as in the case of the legislature and the executive. In the case of the latter the checks and balances are principally through the Constitution, as enforced by the courts, and through the political process. In the case of the courts these checks and balances cannot be through the political process, for this would undermine the independence of the judiciary, which in turn would seriously undermine the judiciary's crucial function of being a check on the legislature and executive. It is therefore unfortunate that the expression "accountability" has been used in relation to the judiciary, for it suggests, wrongly and misleadingly, that the checks and balances on the judiciary are political in nature.

At the same time I should like to stress, as clearly as I can, that the judiciary is not, and does not regard itself as being, above the Constitution or exempt from checks and balances. It must at the same time be appreciated that the checks and balances on the judiciary are different and in most cases also operate indirectly. Their main features seem to me to be the following:

(a) In the first place it is possible for the appointment process to be such that it ensures that persons are appointed to the judiciary who are suitably qualified, both intellectually and ethically, to serve the Constitution and the law; who have the commitment to do so without qualification and who will accordingly regard their oaths of judicial office as being unconditionally binding on their consciences.

(b) Second, all courts function in the most transparent manner possible, not only in the conduct of their hearings but in furnishing reasons for the conclusions and judgments they reach. The obligations to furnish reasons for their judgments, such reasons becoming more comprehensive the higher the particular court is in the hierarchy of courts, is probably the most powerful mechanism to ensure that courts operate under and within the constitution and the law. These reasoned judgments are public documents and open to the scrutiny of colleagues in all other courts, to other lawyers in all branches of the legal professions and to all members of the public. They are open to 
criticism by anyone who cares to do so. There is no limit to such criticism, provided it does not misrepresent the content or conclusions of the judgment, the facts or the law on which it is based or wrongly ascribes dishonest or improper motives to the court which has delivered the judgment. Critical rationalism is, I believe, the best and safest method of arriving at the truth generally, which is one of the reasons why freedom of expressions is such a fundamental liberty. Critical rationalism is no less important in applying and developing the law and keeping a check on those who perform this function.

(c) Third, provision is made for the judgments of all courts (except those of the Constitutional Court and those of the Supreme Court of Appeal in matters which are not of a constitutional nature, in the sense already described) to be taken on appeal to a higher court where they can be corrected. Courts of appeal have never hesitated to correct judgments, where this is warranted, nor to criticise judicial officers where they have acted incorrectly or behaved improperly.

(d) Fourth, in the case of the Constitutional Court in particular, from which there is no further appeal, the opportunity, I would even call it a constitutional duty, for public scrutiny and criticism becomes all-important as a safeguard. The efficacy of informed and rational public scrutiny and criticism, as a means of legitimately "checking" judicial conduct, especially of the highest courts, must not be underestimated, particularly not in a constitutional state which has made the radical shift away from the Westminster parliamentary supremacy of the past. On the assumption that the appointment and promotion procedures work adequately, the judges on the highest courts, through their training and experience, will have become steeped in the habits of rational analysis, argument, criticism and hypothesis formation. This will have become an integral, I would venture to say an inseparable, part of their legal thinking. Few judges would confess to actually liking criticism, but the better informed and the more rationally structured criticism is, the less these judicial habits are able to resist following the arguments. Criticism which is based, whether intentionally or not, on a false substratum of fact or law, is counterproductive. If public debate is regularly premised on such false substratum, whoever might be responsible for supplying it, the natural tendency is to ignore such 
debate as unreliable and in this way the good is lost with the bad.

(e) Fifth, in extreme cases judges may be removed from office for incapacity, gross incompetence and gross misconduct in the manner already alluded to.

(f) Lastly, the Constitution makes provision for national legislation to provide for procedures for dealing with complaints about judicial officers. Such legislation will have to comply with the Constitution and not interfere with judicial independence itself. There is no reason to think that procedures cannot be devised which, while not harming judicial independence, can deal appropriately with judicial misconduct so as to be an effective check on unconstitutional judicial actions. Attention is already being given to such legislation.

While informed and rational criticism of the judiciary performs an important constitutional function, the deliberate undermining of this indispensable independent institution comes close to treason. While judges are not sacrosanct, the institution which they serve is. By and large, following the exemplary lead given by President Mandela, legislative and executive organs have, almost without exception, been scrupulous in their conduct towards the Constitutional Court as a constitutional institution. The example of President Mandela I refer to above relates to his response to the judgment of the Constitutional Court dealing with the provisions of section 16A of the Local Government Transition Act 209 of 1993 ("the LGTA") which purported to give the President the power to amend the LGTA by proclamation. ${ }^{28}$ The President, relying on section $16 \mathrm{~A}$ and legal advice he had been given, purported to amend the LGTA by means of two proclamations. The matter was politically sensitive and had potentially far-reaching implications for the holding of local government elections in the Cape Town metropolitan area. The Court held that the provisions of section16A of the LGTA were constitutionally invalid and that the President had acted unconstitutionally in purporting to amend the provisions of the LGTA by proclamation under the authority of section 16A. The same day on which the Court's judgment was delivered, President Mandela appeared on the public media. He explained that he had acted in good faith and in reliance on legal advice given to him. He did not question

28 Executive Council of the Western Cape Legislature and Others $v$ President of the Republic of South Africa 1995 (10) BCLR 1289 (CC). 
the correctness of the Court's decision but, more importantly, he stressed that the Court was the final constitutional arbiter on the constitutionality of his presidential actions, that the Constitution was supreme and that the Court's judgment had unconditionally to be followed.

It is somewhat paradoxical that the only substantial attacks on the Constitutional Court, calculated to impair it as an institution, have come from political minorities who, one would have thought, would be particularly anxious to rely on such an institution to protect its individual rights against the political majority. The most significant example of such an attack is that referred to in the Sarfu judgments of the Constitutional Court. ${ }^{29}$ The recusal application launched by doctor Luyt against members of the Constitutional Court was unprecedented. It attacked the integrity of every member of the Constitutional Court, "contrasting their integrity and courage (perceived to be flawed) with that of the Judge [in the High Court] (who was said to have shown remarkable courage in giving the judgment that he did)." ${ }^{30}$ The implication of the allegations against all ten members of the Court was stated in the recusal judgment to be -

... that the ten members of this Court had created the impression that they had already decided to uphold the appeal of the President at a time when the record had not been filed and before argument on behalf of any of the parties had been heard. Having so decided, the further consequence of this impression was that they made interlocutory rulings aimed at upholding the President's appeal. The suggestion that a court, without having seen the record or heard argument, would engineer its interlocutory rulings to favour a decision it had already taken, is extraordinary and contemptuous. ${ }^{31}$

In the judgment on the merits the following was said of similar tactics:

29 The President of the Republic of South Africa $v$ The South African Rugby Football Union CCT 16/98. The first Constitutional Court judgment (the forum judgment) is reported in 1999 (2) BCLR 175 (CC), the second (the recusal judgment) is reported in 1999 (7) BCLR 725 (CC) and the third (the judgment on the merits) was delivered on 10 September 1999 but, as at the date of drafting this paper, had not yet been reported.

30 The judgment on the merits, above n 29 at par 251. 
The tactics adopted by Dr Luyt bear the hallmark of spin-doctoring by a respondent who, knowing that the appeal might succeed, lays the ground to discredit the Court with the object of undermining a decision which might go against him. The appellants might succeed, but it would be a pyrrhic victory, secured by a dishonest President from a compliant Court. $^{32}$

For the sake of constitutionalism, it is essential to distinguish between, on the one hand, honest and informed criticism of the judgments and behaviour of judges and, on the other, conduct calculated to undermine the judiciary as an institution.

One of the reciprocal obligations which a constitutional democracy imposes on all its subjects is to support the independent constitutional institutions, as constitutional institutions, not only vocally at the level of intellectual abstraction, but by actively working to establish the habits of constitutionalism in all societal structures and societal interaction. Our constitutional playing fields are well constructed and planted, but require careful tending. 


\section{Bibliography}

Popper Open Society 120-121

Popper KR The Open Society and its Enemies 5 th ed (First Princeton Paperback Printing 1971)

\section{Register of acts}

Constitution of the Republic of South Africa Act 108 of 1996

Constitutional Court Complementary Act 13 of 1995

Electoral Commission Act 51 of 1996

Local Government Transition Act 209 of 1993

\section{Register of cases}

Ferreira $v$ Levin NO and Others; Vryenhoek and Others $v$ Powell NO and Others 1996 (1) BCLR 1 (CC) par [27-30]

New National Party of South Africa v Government of the RSA and Others 1999 (5) BCLR 489 (CC)

Executive Council of the Western Cape Legislature and Others $v$ President of the Republic of South Africa and Others 1995 (10) BCLR 1289 (CC)

The President of the Republic of South Africa and Others $v$ The South African Rugby Football Union and Others CCT 16/98 1999 (2) BCLR 175 (CC)

The President of the Republic of South Africa and Others $v$ The South African Rugby Football Union and Others CCT 16/98 1999 (7) BCLR 725 (CC) 